\title{
東京都・北京市・ソウル市の地域冷暖房事業に関する比較研究 A COMPARISON STUDY ON DISTRICT HEATING AND COOLING IN TOKYO, BEIJING, AND SEOUL
}

\author{
李 花*, 川瀬 貴 晴** \\ Hua LI and Takaharu KAWASE
}

\begin{abstract}
This paper presents the study of DHC (district heating and cooling) business in 3 northeast Asian cities-Tokyo, Beijing and Seoul, in which, projects like initial background, annual fluctuation, current status and heat rate system were investigated. The difference and the feature of DHC use in the city in a country different through the comparison of three cities are analyzed, As a result, this paper may propose a material for DHC business progressing and a new way about the environmental policy in the future. During the period of 2006, DHC annual sales showed big differences in 3 cities. It can be seen that sales for houses and Commercial buildings were also different. The differences of the heat rate unit price by the heat service area of the DHC were large in Tokyo, while small in Beijing and Seoul. Additionally, by use of the building thermal model and comparing individual heat source system, the difference between DHC heat rates in 3 cities is confirmed.
\end{abstract}

Keywords : District Heating and Cooling, Northeast Asian region, current status, Heat rate simulation

地域冷暖房事業，北東アジア都市，事業現状，熱料金シミュレーション

\section{1. はじめに}

地域冷暖房とは、1 箇所または数箇所のプラントから複数の建物に 配管を通して泠水・温水（蒸気）を送って冷房・暖房・給湯を行う システムのことで、比較的高密度に建物が建つ地域につくられる。 世界で最初の地域暖房システムは、1875 年ドイッのハンブルクで誕

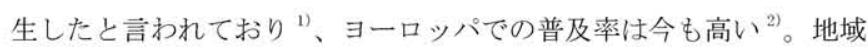
冷暖房は個別冷暖房を集約化したもので、規模のメリットがあるほ かにもゴミ焼却エネルギー、地熱エネルギー、河川エネルギー、バ イオマスエネルギー等未利用エネルギー活用の面でも有利である。 反面、初期費用が高く費用の回収年数も長いために、公共事業並み の優遇政策などのバックアップが重要であるが、地域冷暖房の費用 対効果についての評価は国や地域によって異なる。

北東アジア地域では、東京都は 1971 年、北京市は 1958 年、ソウル 市は 1985 年に地域冷暖房事業が開始され、2006 年時点で東京都が建 築延床面積全体の $4.8 \%$ 注1)、北京市が建築延床面積全体の $64.4 \%$ \% ソウル市が家屋戸数全体の $15.6 \%$ 注3) の建物で地域冷暖房が利用され ている。隣国の都市でありながら、事業の開始時期と普及度には大 きな差があるとも言える。このような傾向は 3 都市の所在国の情況 が違うため当然のこととも言えるが、エネルギーの海外依存度が高 い東京都とソウル市、経済高度成長によるエネルギー不足が懸念さ れる北京市において、エネルギー総合利用とグリーンエネルギー利
用に有利な地域冷暖房の活用は大きな課題であり、今後の適切な展 開を図る上で、各国の地域冷暖房事業の状況を比較して検討寸るこ とは大きな意義がある。また、それらの地域冷暖房を所在国が異な る隣国の地域椧暖房と横並びにした比較研究を通じて、各国のそれ までの環境政策と事業モデル範囲での検討では容易に発見できない 示唆を引き出し、より大きな枠組みで考え直すきっかけとなりうる 要素を探ることができるのではないかと考える。

既往の研究をみると、東京都は熱需要特性による地区分類研究 ${ }^{3)}$ 、

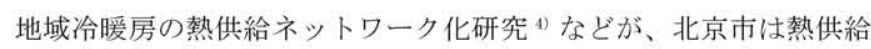
面積による定額制熱料金制から熱使用量による従量制熱料金制へ転 換関連の研究 ${ }^{5)}$ 、それに伴う熱計量器の研究が、ソウル市は外気温度 変動による地域暖房の暖房負荷変動特性分析 ${ }^{6)}$ 、活用可能な未利用エ ネルギーと冷暖房負荷の関連性研究 7 など異なる研究傾向を持ちな がら 3 都市とも幅広い研究がされている。なお、それぞれ本国や本 拠地を研究対象にしていて、他国や他地点の地域泠暖房は事例とし て紹介されることにとどまり、横並びにした研究はほとんどない。 本研究では、北東アジア地域にある東京都、北京市、ソウル市を対 象に地域冷暖房事業の開始背景と最近 10 年間の変動、事業の現状、 熱料金体系等の項目について調查を行い、3 都市の比較を通じて異な る国の都市での地域泠暖房利用の違いや特徵を分析し、それにより 今後の域冷暖房事業の展開や環境政策のあり方を考えるための資料

\footnotetext{
* 千葉大学大学院工学研究科 博士後期課程

** 千葉大学 教授. 工博
}

Graduate Student, Chiba University Prof., Chiba University, Dr. Eng. 
を提供することを目的にしている。

\section{2. 研究対象および研究方法}

\section{1 研究対象の概要}

表 1 に 3 都市の概要を示す。 3 都市の土地面積には析違いの差があ るが、人口はそれほどの差がなく、どれも 1 千万人以上の人々が暮 らしている巨大都市である。緯度からみると東京都が一番南に位置 し、北京市は日本の盛岡、ソウル市は福島とほぼ同じ緯度に位置し ている。

図 1 は 3 都市の 2006 年の月平均気温と月平均湿度によるクリモグ ラフである。夏季の温湿度差はあまりないが、冬季の 1 月平均気温 は東京都がソウル市より $5.3^{\circ} \mathrm{C}$ 、北京市より $7^{\circ} \mathrm{C}$ も高い。北京市とソ ウル市は冬の寒さが厳しく、暖房対策は日常生活で久かせない重要 な事項である。

\section{2 研究方法}

東京都、北京市、ソウル市における地域冷暖房事業について以下の 4 つの項目を調查し、比較分析を行なう。

(1)最初の地域冷暖房事例の開始時期、開始された背景、熱供給能力 (2)最近 10 年間の地域泠暖房事業の年間熱販売量の状況

(3)地域冷暖房事業の現状 (2006 年度)

(4)地域冷暖房の熱料金体系と、モデル (住宅、事務所) 建物を使用 した熱料金シミュレーション

調查は文献収集、地域冷暖房プラント訪問調查、電話によるインタ ビュー等の手法で行なう。

\section{3. 最初の地域冷暖房事例比較}

3 都市の地域冷暖房は、それぞれ異なる時期にその時代の社会背景 のもとに登場している。表 2 に各都市最初の地域冷暖房事業を示す。 東京都は、大気污染が社会的に問題になりはじめた 1955 年に「ば い煙防止条例」を制定したが、その後も暖房用ボイラからの黒煙と 亜硫酸ガスを対象に、ばい煙発生源を集中して、污染物質の共同処 理をはかることを主旨にする対策案が検討された。1971 年に「都民 を公害から防衛する計画」を発表し、事業所集中地区、新開発、再 開発地区に地域冷暖房を推進することにした。そして、1971 年 4 月 に新宿新都心地区で地域冷暖房が導入され、東京都庁舎、京王プラ ザホテル、新宿パークタワー等 15 棟の建物に熱供給を予定し、京王 プラザホテルのオープンに合わせて熱供給を開始した。 ${ }^{12) 13) 。 ~}$

北京市は、3 都市のなかでは一番早い 1956 年にドイツの協力で、 初の地域暖房システムである北京電子動力会社熱電所を建設し、 1958 年に北京第一熱電所より、光華染織工場を含む 9 つの工場と合 成繊維工場宿舎の 2.75 万 $\mathrm{m}^{2}$ で、熱供給を開始した ${ }^{14)}$ 。当時は政府に よる計画経済制度のもとに、市民の住環境改善の対策として導入さ れた。住宅用の暖房は政府の福祉事業として無償で行なわれ住民の 負担はなく、当然熱計量も行なわれてなかった。

ソウル市は、1985 年モクトン地区でニュータウン開発が行なわれ、 開発区域内の集合住宅暖房方式に、当時北欧で開発・普及が進んで いた熱電併給発電を利用した地域暖房方式が導入され、11月にS H 公社 (旧ソウル市集団エネルギー) が、モクトン地区の 1 団地への 熱供給を開始した。全体の工事は 1987 年に終了し住居用、営業用、 および公共用建物に熱供給を行う同時に、同地区所要電力量の $1 / 7$
表 1 研究対象の概要 (2006 年 $)^{8) 9) 10) 11)}$

\begin{tabular}{c|c|c|c}
\hline 項目 & 東京都 & 北京市 & ソウル市 \\
\hline \hline 地理位置 & $\begin{array}{c}\text { 北緯 } 35 \text { 度 } \\
\text { 東経 } 139 \text { 度 }\end{array}$ & $\begin{array}{c}\text { 北緯 } 39.9 \text { 度 } \\
\text { 東経 } 116.3 \text { 度 }\end{array}$ & $\begin{array}{c}\text { 北緯 } 37 \text { 度 } \\
\text { 東経 } 127 \text { 度 }\end{array}$ \\
\hline 土地面積 & $2,187 \mathrm{k} \mathrm{m}^{2}$ & $16,410 \mathrm{k} \mathrm{m}{ }^{2}$ & $605 \mathrm{k} \mathrm{m}^{2}$ \\
\hline 人口 & 1,234 万人 & 1,581 万人 & 1,034 万人 \\
\hline 世帯数 & 593 万 & 464 万 & 398 万 \\
\hline 年平均気温 & $16.4^{\circ} \mathrm{C}$ & $13.4^{\circ} \mathrm{C}$ & $13.0^{\circ} \mathrm{C}$ \\
\hline
\end{tabular}

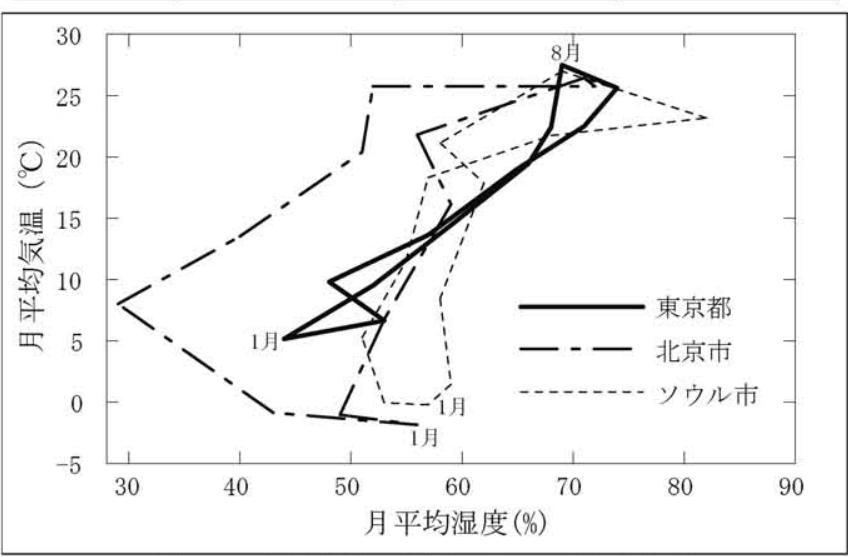

図 $1 \quad 3$ 都市クリモグラフ $(2006 \text { 年 })^{899) 10) 11)}$

表 2 最初の地域冷暖房事例

\begin{tabular}{|c|c|c|c|c|}
\hline 都市名 & 開始時期 & $\begin{array}{c}\text { 区域名 } \\
\text { (事·業者名) }\end{array}$ & 配管延長 & 熱源設備能力 \\
\hline 東京都 & 1971 年 & $\begin{array}{l}\text { 新宿新都心地区 } \\
\text { (東京瓦斯(株)) }\end{array}$ & 3. $0 \mathrm{~km}$ & $\begin{array}{l}\text { 冷房 : } 42 \mathrm{GJ} / \mathrm{h} \\
\text { 暖房 : } 80 \mathrm{GJ} / \mathrm{h}\end{array}$ \\
\hline 北京市 & 1958 年 & $\begin{array}{c}\text { 光華染織地区 } \\
\text { (北京第一熱電所) }\end{array}$ & 13. $4 \mathrm{~km}$ & 暖房 : $2016 \mathrm{GJ} / \mathrm{h}$ \\
\hline $\begin{array}{c}\text { ソウル } \\
\text { 市 }\end{array}$ & 1985 年 & $\begin{array}{c}\text { モクトン地区 } \\
\text { (S H公社) }\end{array}$ & $20.0 \mathrm{~km}$ & 暖房 : $2482 \mathrm{GJ} / \mathrm{h}$ \\
\hline
\end{tabular}

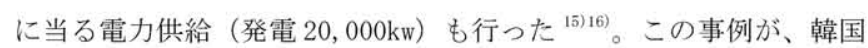
地域冷暖房協会が承認するソウル ( 又は韓国) 初の地域暖房事例で あり、韓国では電気と熱を併給する大規模システムを地域泠暖房と 称寸ることが一般的である。ただし、ボイラー専用の地域暖房事例 は 60 年代からある。例をあげると、1970 年竣工の漢江地区の大韓 住宅公社アパート群 5 階建 23 棟、延床面積 8 万 $\mathrm{m}^{2}$ を対象として中温 水 $\left(115^{\circ} \mathrm{C} / 85^{\circ} \mathrm{C}\right)$ を使用した熱出力 $212 \mathrm{Gcal} / \mathrm{h}$ の事例である ${ }^{16)}$ こ こでは、建物と地域暖房の建設・管理が同じ建設会社によって行わ れていた。

\section{4. 最近 10 年間の地域冷暖房事業の状況比較}

3 都市の地域冷暖房事業の近年の成長を考察するために、最近 10 年間の年間熱販売量を調查し、比較を行った。ここで、東京都は日 本熱供給事業協会「熱供給事業便覧」(平成 11 年版 平成 20 年版) の数值を、北京市は中国国家統計局「中国統計年鑑」(1999～2008) の数值を、ソウル市は熱供給会社から直接提供された数值を用いた。

図 2 に都市別の $1998 \sim 2007$ 年の地域冷暖房年間熱販売量の経年 変化を、図 3 に 1998 年を基準にした地域冷暖房年間熱販売量の増 加率を示す。 
グラフより、年間熱販売量は北京市は東京都の最大 12.2 倍とソウ ル市の最大 8.3 倍、ソウル市は東京都の最大 1.6 倍であることがわ かる。また、1998 年を基準にした年間熱販売量の増加率は、北京市 が最大 $63 \%$ 、ソウル市が最大 $55 \%$ に対して、東京都はその半分の最 大 $27 \%$ にとどまることがわかる。また、ここで、 3 都市の 2005 年度 の年間熱販売量が最も多くなっているが、その要因は経済活動の変 化や地域冷暖房熱供給対象の変化による影響ではなく、気候の変化 による影響であると考えられる。

\section{5. 地域冷暖房事業の現状比較}

3 都市の地域冷暖房事業の現状を考察するために、2006 年度を対象 として地域冷暖房の年間熱販売量、事業者の状況、エネルギー使用 効率を比較する。

\section{1) 年間熱販売量比較}

図 4 に各都市 2006 年度の地域冷暖房年間熱販売量を示す。全体の 年間熱販売量は東京都が 1298 万 GJ、北京市が 15808 万 GJ、ソウル 市が 1903 万 GJ であり、北京市がほかの都市より圧倒的に多い。住 宅向けが全体に占める割合は東京都が $3 \%$ 、北京市が $66 \%$ 、ソウル市 が $92 \%$ で、ったく異なる熱供給対象となっていて、東京都とソウ ル市は正反対となっている。また、年間熱販売量の内、冷熱販売量 の割合は東京都が約 64\%、北京市はほぼ $0 \%$ 、ソウル市が約 $1 \%$ であり、 事務所向けが主体の東京都と他の 2 都市では、明確な差がある。東 京都は 66 力所の地域冷暖房区域の内、64 力所で泠熱販売があるに 対して、ソウル市は地域冷暖房の対象である 524 棟の事務所ビルの 内、59 棟に冷熱販売がある。住宅向けは、3 都市とも温熱が主で泠 熱販売は一部の高級タワービルに限る。

\section{2 ) 事業者の比較}

表 3 に 3 都市の地域冷暖房事業者の概要を示す。年間熱販売量は、 北京市がほかの都市より 10 倍程度多いが、事業者の数はそれを上回 る数千倍もある。それとは対照的に、ソウル市はわずか 2 社の事業 社がソウル市全体の地域冷暖房事業を担っている。1 区域当たりの 平均年間熱販売量を計算すると、東京都が $20 \mathrm{GJ}$ 、北京市が $3 \mathrm{GJ} 、 ソ$ ウル市が 380GJ で区域当たりの規模はソウル市が大きい。

\section{3 ) エネルギー使用効率の比較}

地域冷暖房システムには、熱源設備、熱配管、受熱側機器等があり、 設備の種類と使用年数、配管距離、システム運転方式等によってエ ネルギー使用効率には差がある。地域冷暖房システムのエネルギー 使用効率の評価は多数の要因を考慮する必要がある複雑な問題であ り、また対象とするシステムの数も多いため正確な効率を求めるの は難しく、本研究とは別に研究す心゙きテーマと考えているが、簡単 な方法で 3 都市の概略のエネルギー使用効率を考察するのは可能で ある。ここでは、地域冷暖房システムにおいて、熱量と電気量の 2 要因のみを考慮し、エネルギー使用効率を計算する。計算のなかで、 東京都は電力の一次エネルギー換算値として $1 \mathrm{kwh}=9.76 \mathrm{MJ}$ (全日) を、 都市ガスは「熱供給事業便覧」の換算值 $1 \mathrm{~N} \mathrm{~m}^{3}=41.1 \mathrm{MJ}$ を利用し、ソ ウル市は韓国エネルギー管理公団統計の一次エネルギー計算数値を 直接利用し、北京市は北京市供熱協会「北京供給」の資料を用いた。 また、CGS 排熱利用時は受入れた熱量をそのまま燃料消費量として 扱っている。

計算式は式 1 のおりである。

$$
\eta=(\mathrm{q} 1+\mathrm{q} 2) \div(\mathrm{Q} 1+\mathrm{Q} 2)
$$

$\eta$ : エネルギー使用効率

q1：年間熱販売量 $(2006$ 年度 )

q2：年間電気販売量 (2006 年度)

Q1：年間燃料消費量 (2006 年度)

Q2：年間電気消費量 (2006 年度)

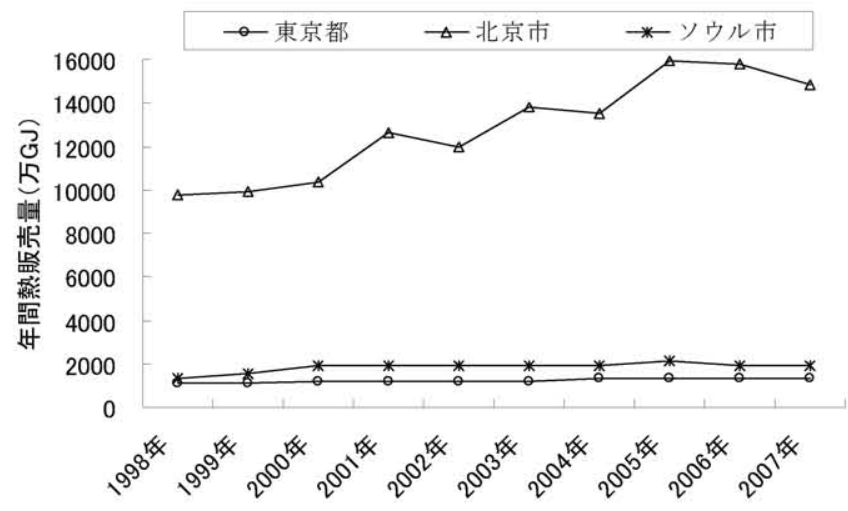

図 2 最近 10 年間の地域冷暖房の年間熱販売量状況 ${ }^{17)(18)}$

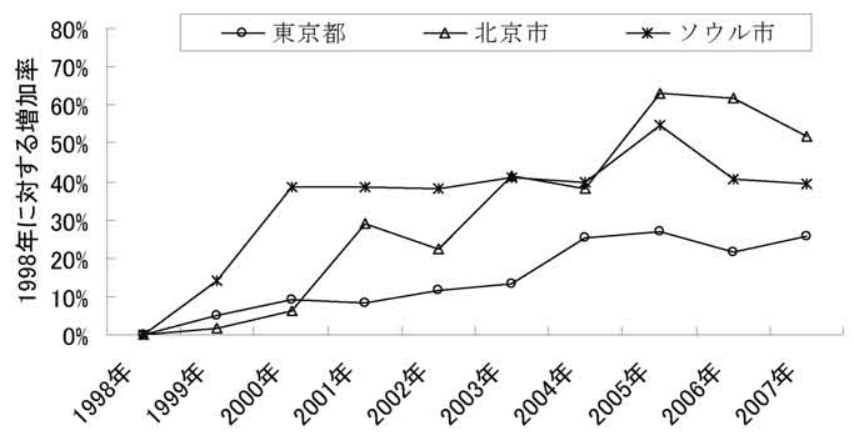

図 31998 年の地域冷暖房年間熱販売量に対する比較

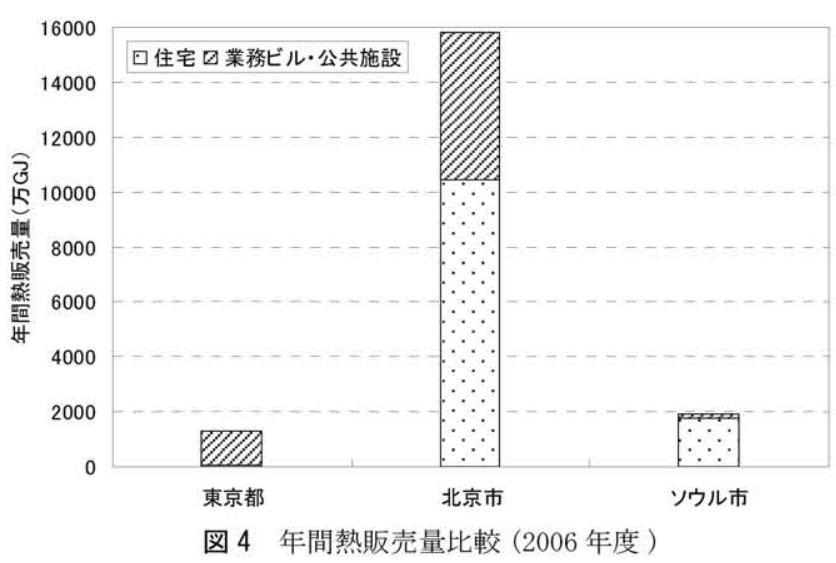

表 3 地域冷暖房事業者比較 (2006 年 ) 19220)21)

\begin{tabular}{|c|c|c|c|c|c|}
\hline 都市名 & \begin{tabular}{|l} 
会社 \\
数
\end{tabular} & $\begin{array}{l}\text { 熱供給 } \\
\text { 区域数 }\end{array}$ & $\begin{array}{l}\text { 熱源設備 } \\
\text { 能力 }(\mathrm{GJ} / \mathrm{h})\end{array}$ & $\begin{array}{c}\text { 最大熱供給区域 } \\
\text { (事学者名) }\end{array}$ & \begin{tabular}{|l} 
最大熱供給区域 \\
熱源没備能力
\end{tabular} \\
\hline 東京都 & 36 & 66 & $\begin{array}{l}\text { 佮房: } 7059 \\
\text { 暖房:7309 }\end{array}$ & $\begin{array}{l}\text { 新宿新都心地区 } \\
\text { (エネルギードバンス) }\end{array}$ & $\begin{array}{l}\text { 椧房: } 747 \mathrm{GJ} / \mathrm{h} \\
\text { 暧房 : } 621 \mathrm{GJ} / \mathrm{h}\end{array}$ \\
\hline 北京市 & 3894 & 5346 & 暖房:30546 & $\begin{array}{c}\text { 華能北京熱電所地区 } \\
\text { (北京市熱力集団) }\end{array}$ & 险房 : $4872 \mathrm{GJ} / \mathrm{h}$ \\
\hline $\begin{array}{l}\text { ソウル } \\
\text { 市 }\end{array}$ & 2 & 5 & \begin{tabular}{|l} 
椧房: 655 \\
暖房:9933
\end{tabular} & $\begin{array}{c}\text { Gangnam 地区 } \\
\text { (韓国地域暖房公社) }\end{array}$ & 䐘房: $3011 \mathrm{GJ} / \mathrm{h}$ \\
\hline
\end{tabular}


図 5 にエネルギー使用効率の計算結果を示す。

東京都は、66 力所の地域冷暖房システムのエネルギー使用効率は、 0.6 から 0.9 のシステムが多く、一番高いものは 1.23 にも達している。 熱源設備の燃料は電気とガスが主で、ほかに少量の排熱利用がある。

ソウル市は、 5 カ所の地域冷暖房システムすべてに熱電併給シス テムが活用されている。エネルギー使用効率は、 0.8 以上が 4 力所 と 0.31 が 1 力所である。燃料消費量全体の $36 \%$ が電力公社からの排 熱利用で、そのほかにL N G、L SWR油 (低硫黄重油)、L F G (Land Fill Gas) 等がある。

北京市は、大型熱電併給システム 5 力所と大型ガス燃焼熱供給シス テム 3 カ所による熱供給が全体の $1 / 4$ を占め、それ以外は数千もあ るボイラー専用の小型システムによる熱供給である。各事業者の生 産情報の公開はほとんどなく、北京市供熱協会の論説によると、石 炭燃焼システムの平均稼動効率は 55-60\% で、先進国より 20-25\%低く、 ガス燃焼システムの平均稼動効率は 80\% で、先進国より 10-15\% 低い という ${ }^{20)}$ 。

\section{6. 地域冷暖房の熱料金体系比較}

地域冷暖房システムの初期費用と運転費用は熱料金に反映され、最 終的に熱使用者側が負担する。熱料金体系を如何に合理的に設定す るかは地域冷暖房事業の成否にかかわるもっとも重要な要因の一つ である。地域冷暖房熱料金体系には、主に「従量制料金体系」と「定 額制料金体系」があり、東京都とソウル市は基本料金と従量料金に よる 2 部制の「従量制料金体系」を、北京市は熱供給床面積による「定 額制料金体系」を採用している。3 都市における地域冷暖房の熱料 金体系を比較するために、本研究では以下の 2 項目の比較を行なう。 (1)地域冷暖房の熱料金単価比較

(2)モデル (住宅、事務所) 建物を使用した地域冷暖房熱料金比較

ただし、3 都市の貨幣価值と生活水準の差を考虑するため、地域冷 暖房熱料金を平均世帯月消費支出 (住宅の場合) と不動産月賃貸料 金 (事務所の場合) に対する比率の対比でも比較を行なう。

\section{1 地域冷暖房の熱料金単価比較}

東京都は、「熱供給事業法」第十四条により熱供給事業者は、熱供 給の料金その他の供給条件について供給規程を定め、通商産業大臣 の認可を受けなければならない。

東京都の地域泠暖房の熱料金単価は、全体的に複雑で各熱供給区域 による格差が大きい。同じ事業者による地域冷暖房であっても、熱 供給区域によって差があり、これはほかの 2 都市にはない特徵であ る。図 6、図 7 に東京都の地域冷暖房熱供給区域の 2006 年度熱料金 単価を示す。事務所用熱料金単価の場合、区域により基本料金で最 大 12 倍、従量料金で最大 7 倍の差が生じている。

北京市は、建設部の「都市供熱価格管理暫定法案」と市政府の価格 主管部門により毎年北京市全体で適用する地域暖房の熱料金単価が 決まる。

地域冷暖房事業者に熱料金単価の決定権はなく、市政府が定める熱 料金単価に従う。なお、熱生産コストの一部を市政府が補助しており、 燃料の価格変動によるコスト変動は実質的に市政府が負担すること になるため、事業者の負担は小さく、熱料金単価が 10 年以上も変わっ てない。表 4 に北京市の 2006 年度熱料金単価を示す。

なお、定額制料金体系がエネルギー使用効率の向上や省エネルギー
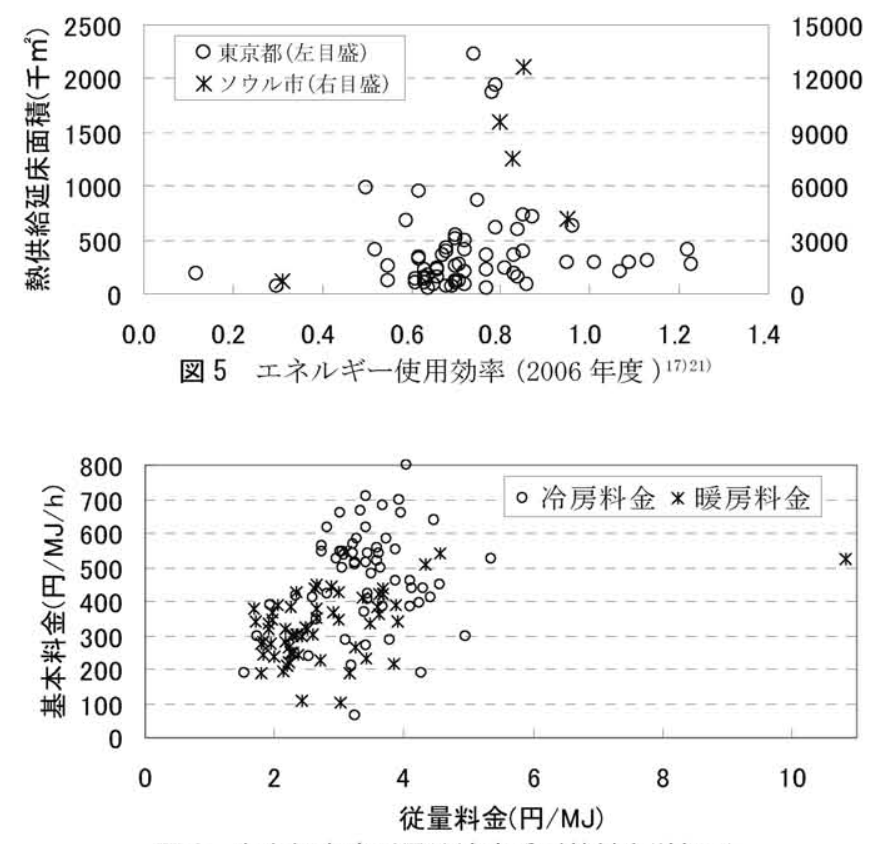

図 6 東京都事務所用地域冷暖房熱料金単価 ${ }^{17}$

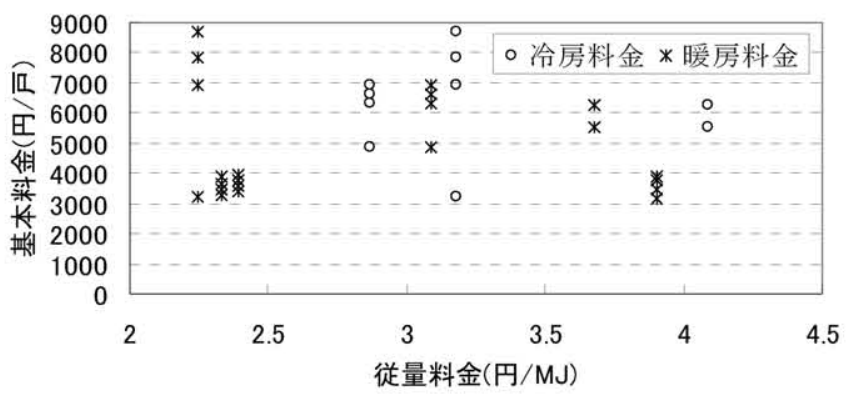

図 7 東京都住宅用地域泠暖房熱料金単価 ${ }^{17}$

志向に不利であることが議論を呼び 22)、2008 年には「市熱力集団」 により市全体の3\%未満に当る区域で「従量制料金体系」を試行し、 熱料金単価（表 5) も特別に設定している。これには熱料金体系を段 階的に定額制から従量制一と転換させようとするねらいがある。

ソウル市は、「集団エネルギー事業法」第 17 条により、熱供給事業 者は熱料金上限審議委員会の審議を受け、産業資源部長官に届け出 し、認可を受ける。

燃料価格の変動による熱料金単価の変動はあるものの、各熱供給区 域による熱料金単価の差は小さく、東京都のような数倍ないし十数 倍になることはない。さらに同じ事業者による熱供給区域であれば、 熱料金単価はまったく同じである。表 6、表 7 にソウル市の地域冷 暖房熱供給区域の 2006 年度熱料金単価を示す。

\section{2 モデル住宅を使用した地域暖房の熱料金比較}

3 都市の平均世帯の生活状況をもとにモデル住宅を設定し、1 暖房 期の暖房用熱消費量について都市別に地域暖房熱料金を計算して比 較を行ない、さらにモデル住宅がルームエアコンを使用した場合の 暖房用料金を計算して地域暖房熱料金と比較を行なう。図 8 に比較 のながれを示す。

\section{1) 都市別の平均世帯生活状況概要およびモデル住宅設定}

モデル化の考え方はいろいろあるが、ここでは都市別に平均世帯の 
表 4 北京市地域暖房熱料金単価（元/ 熱供給面積 $\left(\mathrm{m}^{2}\right)$ - 年） $\left.{ }^{23}\right)$

\begin{tabular}{l|c|c}
\hline \multicolumn{1}{c|}{ 熱源方式 } & 住宅 & 非住宅 \\
\hline \hline 市熱力集団 & 24 & 30 \\
\hline 石炭燃焼ボイラ(直接方式) & 16.5 & 23.5 \\
\hline 石炭燃焼ボイラ(間接方式) & 19 & 26 \\
\hline 燃油ボイラ & 30 & 35 \\
\hline
\end{tabular}

表 5 北京市 2008 年試行の地域暖房熱料金単価 ${ }^{24)}$

\begin{tabular}{c|c}
\hline 基本料金 & 従量料金 \\
\hline \hline 18 元/熱供給面積 $\cdot$ 年 & 0.16 元 $/ \mathrm{kwh}(44.45$ 元/GJ) \\
\hline
\end{tabular}

表 6 ソウル市地域暖房熱料金単価 (基本料金)（ウホン）25)

\begin{tabular}{|c|c|c|c|c|}
\hline 区域名 & 事業者名 & 住宅用 & 事務所用 & 公共用 \\
\hline NamSeoul & \multirow{3}{*}{$\begin{array}{l}\text { 韓国地域 } \\
\text { 暖房公社 }\end{array}$} & $49.02 / \mathrm{m}^{2}$ & 371. 18/Mcal/h & $338.62 / \mathrm{Mcal} / \mathrm{h}$ \\
\hline Gangnam & & $49.02 / \mathrm{m}^{2}$ & 371. 18/Mcal/h & 338. $62 / \mathrm{Mcal} / \mathrm{h}$ \\
\hline Sangam & & $49.02 / \mathrm{m}^{2}$ & 371. 18/Mcal/h & $338.62 / \mathrm{Mcal} / \mathrm{h}$ \\
\hline Gamgseo & \multirow{2}{*}{ S H公社 } & $45.54 / \mathrm{m}^{2}$ & 344. 85/Mcal/h & 314. 60/Mcal/h \\
\hline Nowon & & $45.54 / \mathrm{m}^{2}$ & $344.85 / \mathrm{Mcal} / \mathrm{h}$ & $314.60 / \mathrm{Mcal} / \mathrm{h}$ \\
\hline
\end{tabular}

表 7 ソウル市地域暖房熱料金単価 (従量料金) (ウシン/Mcal) ${ }^{25}$ )

\begin{tabular}{|c|c|c|c|c|}
\hline 区域名 & 事業者名 & 住宅用 & 事務所用 & 公共用 \\
\hline NamSeoul & \multirow{3}{*}{$\begin{array}{l}\text { 韓国地域 } \\
\text { 暖房公社 }\end{array}$} & 53.11 & 74.51 & 65.06 \\
\hline Gangnam & & 53.11 & 74.51 & 65.06 \\
\hline Sangam & & 53.11 & 74.51 & 65.06 \\
\hline Gamgseo & \multirow{2}{*}{ S H公社 } & 73.76 & 110.46 & 96.08 \\
\hline Nowon & & 73.76 & 110.46 & 96.08 \\
\hline
\end{tabular}

生活状況を調查し (表 8)、それをもとに各都市で同一規模のモデル 住宅を設定する (図 9)。モデルの延床面積には 3 都市の平均世帯の 住宅延床面積の平均值を、熱使用量には各都市平均世帯の 1 暖房期 の暖房用熱使用量をもとに面積当たりの熱量を求め、モデル住宅延 床面積に相当する 1 暖房期の暖房用熱使用量を計算した結果を、月 消費支出には各都市平均世帯の月消費支出を適用寸る。

\section{2) 地域暖房熱料金単価の選定}

熱供給区域によって地域暖房熱料金単価に差があるため、その都市 を代表する単価を選定する必要がある。

東京都は、住宅向けの熱販売がある 13 区域のなかで熱販売量が多 い6 区域を選び、各区域の熱供給延床面積を加味した平均熱料金単 価を採用した。その結果、基本料金は 70〜80 $\mathrm{m}^{2}$ 未満 4099 (円/戸)、 従量料金は2.403(円/MJ) になった。北京市は、北京市熱力集団の 熱料金単価（表 4) の 24 （元 / 熱供給面積 $\left(\mathrm{m}^{2}\right)$ ・年）を適用する。 ソウル市は、地域暖房熱販売量全体の 6 割を占める韓国地域暖房公 社の熱料金単価（表 6、表 7) の基本料金 49.02 (ウォン/ $\mathrm{m}^{2}$ )、従量料 金 53.11（ウォン /Mcal）を適用する。

\section{3）地域暖房の熱料金計算・比較}

1) で設定したモデル住宅条件と 2 ) の地域暖房熱料金単価により、 モデル住宅の 1 暖房期にかかる地域暖房熱料金を計算し、その結果 を平均世帯月消費支出に対する比率の対比で比較を行なう。表 9 に その計算結果を示す。

比率が一番高いのは北京市、次がソウル市で東京都がもつとも低い。

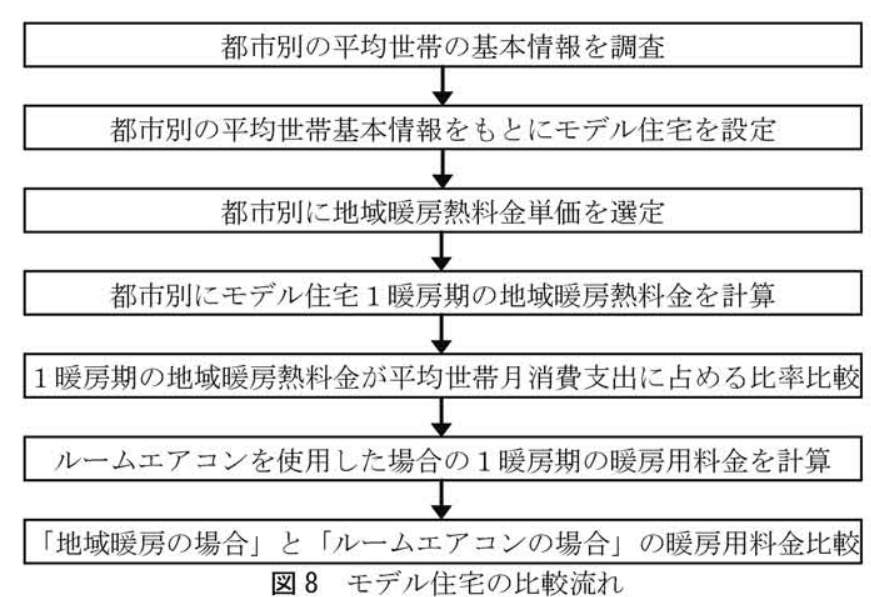

表 8 都市別平均世帯の生活状況概要 ${ }^{899) 1126(27) 28)}$

\begin{tabular}{|c|c|c|c|}
\hline 項目 & 東京都 & 北京市 & ソウル市 \\
\hline 1 ケ月実収入 & 585, 818 円 & 5,417 元 & 3, 204, 900 ウォ゙ \\
\hline 1 ヶ月消費支出 & 350,664 円 & 3,583 元 & 2, 199, 600 ウオン \\
\hline 住宅延床面積 & $64.2 \mathrm{~m}^{2}$ & $77.3 \mathrm{~m}^{2}$ & $83.6 \mathrm{~m}^{2}$ \\
\hline $\begin{array}{c}1 \text { 暖房期の } \\
\text { 暖房用熱使用量 }\end{array}$ & $9,868 \mathrm{MJ}$ & $33,162 \mathrm{MJ}$ & $39,625 \mathrm{MJ}$ \\
\hline \multicolumn{4}{|c|}{ 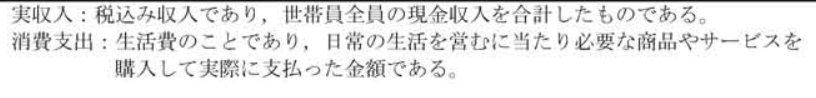 } \\
\hline 東京都 & 北京 & & ソウル市 \\
\hline $\begin{array}{l}\text { 延床面積 : } 75 \mathrm{~m}^{2} \\
\text { 熱使用量 : } 11,528 \mathrm{NJ} \\
\text { 月消費支出 : } 350,664 \text { 円 }\end{array}$ & $\begin{array}{l}\text { 延床面積 : } \\
\text { 熱使用量 : } \\
\text { 月消費支出 }\end{array}$ & $\begin{array}{l}\mathrm{m}^{2} \\
175 \mathrm{WJ} \\
3,583 \text { 元 }\end{array}$ & $\begin{array}{l}\text { 延床面積 : } 75 \mathrm{~m}^{2} \\
\text { 熱使用量 : } 35,549 \mathrm{WJ} \\
\text { 月消費支出 : } 2,199,600 \text { 林: }\end{array}$ \\
\hline
\end{tabular}

図 9 モデル住宅条件設定

この結果には地域暖房料金単価の要因だけでなく、東京都の暖房用 熱使用量が小さい要因も無視することはできないが、北京市の地域 暖房料金が家計での負担が一番大きいのは明確である。

\section{4 ）「地域暖房の場合」と「ルームエアコンの場合」の比較}

住宅の暖房方式には、地域暖房以外にも様々な方式があり、地域暖 房料金の高低を評価するには個別の暖房方式にかかる暖房料金と比 較する必要がある。本研究では、その一例としてルームエアコン方 式の場合を想定して暖房料金を計算し、地域暖房熱料金と比較した。 表 10 に比較に使用するルームエアコンの条件を示す。機器は各都 市の大手家電メーカーが 2009 年に公表している製品カタログより、 最新型の商品を選ぶ。モデル住宅の床面積に相応して機器台数は 3 台とし、機器使用時間や能力にはバラツキがあるものの、本研究で 選んでいる機器毎の COP の差は僅差であることから、単純平均で求 めた機器平均 $\mathrm{COP}$ を適用して、電気使用量を求める。機器価格に関 しては、販売時期やメーカーの販売戦略によって大きく変動するた めに、2009 年 12 月時点に同時に検索した価格を適用する。耐用年 数は 10 年と想定し、年間機器コストを計算する。電気料金は各都市 電力会社の住宅用低圧電気料金単価を適用する。

上記の条件をもとに、都市別にモデル住宅の暖房方式がルームエア コンの場合の 1 暖房期にかかる暖房料金を計算する。 
表 9 モデル住宅における 1 暖房期地域暖房熱料金

\begin{tabular}{c|c|c|c}
\hline 項目 & 東京都 & 北京市 & ソウル市 \\
\hline \hline 地域暖房熱料金 & 45,902 円 & 1,440 元 & 493,641 ウホン \\
\hline 円換算 & 同上 & 22,154 円 & 49,364 円 \\
\hline $\begin{array}{c}\text { 平均世帯月消費 } \\
\text { 支出に対する比率 }\end{array}$ & $13.1 \%$ & $40.2 \%$ & $22.4 \%$ \\
\hline
\end{tabular}

表 10 ルームエアコン条件

\begin{tabular}{l|c|c|c}
\hline \multicolumn{1}{c|}{ 項目 } & 東京都 & 北京市 & ソウル市 \\
\hline \hline 機種及び台数 & $\begin{array}{l}\text { S40KTRXP-1 台 } \\
\text { S22KTRXS-2 台 }\end{array}$ & $\begin{array}{c}\text { KFRd-35GW-1 台 } \\
\text { KFRd-26GW-2 台 }\end{array}$ & AR-F7S-3 台 \\
\hline 機器メーカー & DAIKIN & Haier & SAMSUNG \\
\hline 機器平均COP & 5.7 & 3.6 & 4.2 \\
\hline 年間機器コスト & $38,200 円 ~$ & 1,149 元 & 204,000 ウォン \\
\hline 注: 機器のメンテナンス覜は考虑しない
\end{tabular}

図 10 に「地域暖房の場合」と「ルームエアコンの場合」の暖房用 熱料金を平均世帯月消費支出に対する対比で比較した結果を示す。 東京都と北京市のルームエアコンの電気料金は地域暖房熱料金より 安いが機器コストを考慮すると地域暖房熱料金より高い結果となっ た。ソウル市はルームエアコンの電気料金のみでも地域暖房熱料金 より大幅に高く、機器コストを上乗せするともっと高くなる。ソウ ル市の住宅用電気料金体系は電気使用量による段階料金の単価増加 率がほかの都市より格別に大きく、ルームエアコンには不利である 結果となった。これは、ソウル市で住宅向けの地域暖房が進んでい る裏付けにもなる。

\section{3 モデル事務所を使用した地域冷暖房の熱料金比較}

モデル事務所を設定し、1 年間の泠暖房用熱消費量について都市別 に地域冷暖房料金を計算して比較を行い、さらにモデル事務所が個 別冷暖房を使用した場合の冷暖房料金を計算して地域冷暖房熱料金 と比較を行う。図 11 に比較のながれを示す。

\section{1) モデル事務所設定}

表 11 にモデル事務所の建物概要と空調運転状態を示す。 3 都市と もに同条件のモデルを設定する。

\section{2) 空調用熱負荷計算方法}

New HASP/ACLD (Ver. 20091117) ソフトを利用して、モデル事務所 の東京都、北京市、ソウル市における空調用熱負荷を計算する。計 算に必要な気象データに関しては、東京都はソフトに同梱されてい る東京都標準年気象データ (3639999. has) を使用する。なお、New HASP/ACLD は日本での使用を前提にしているために、北京市とソウ ル市は米国エネルギー省 ${ }^{29)}$ が公開しているエネルギー消費量算出 ッール「EnergyPlus」用の気象データ (以下 EPW データ) を、New HASP 用 (以下 has データ) に変換した。表 12 に EPW データによる has データの変換方法を示す。

図 12、図 13 に 3 都市における月別積算空調用熱負荷とピーク時冷 暖房熱負荷の計算結果を示す。

\section{3）地域冷暖房の熱料金計算・比較}

図 12 の空調用熱負荷量をモデル事務所の地域冷暖房による熱消費 量として見なし、地域冷暖房熱料金を計算する。各都市の地域冷暖 房熱料金単価は、東京都は丸の内熱供給社の各熱供給区域熱料金単 価 (2006 年度) の平均值を、北京市は北京市熱力集団の熱料金単価

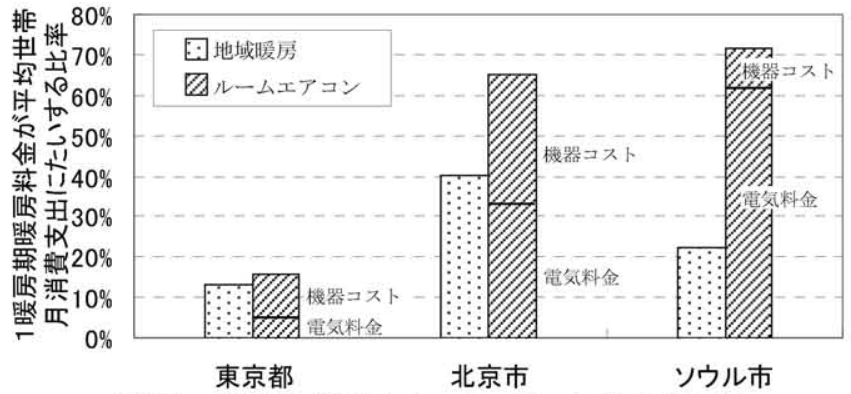

図 10 地域暖房料金とルームエアコン料金の比較

\begin{tabular}{|c|c|}
\hline \multicolumn{2}{|c|}{ モデル事務所設定 } \\
\hline & \\
\hline \multicolumn{2}{|c|}{ 都市別にモデル事務所の空調用熱負荷シミュレーション } \\
\hline \multicolumn{2}{|c|}{1} \\
\hline \multicolumn{2}{|c|}{3 都市のシミュレーション結果比較 } \\
\hline \multicolumn{2}{|c|}{1} \\
\hline \multicolumn{2}{|c|}{ 都市別に地域冷暖房熱料金単価を選定 } \\
\hline \multicolumn{2}{|c|}{$\frac{1}{1}$} \\
\hline \multicolumn{2}{|c|}{ 都市別にモデル事務所 1 年間の地域冷暖房熱料金を計算 } \\
\hline \multicolumn{2}{|c|}{$\downarrow$} \\
\hline \multicolumn{2}{|c|}{ 年間地域冷暖房料金が不動产の月賃貸料金に占める比率比較 } \\
\hline \multicolumn{2}{|c|}{1} \\
\hline \multicolumn{2}{|l|}{ 都市別に「個別熱源方式」熱 } \\
\hline \multicolumn{2}{|c|}{1} \\
\hline \multicolumn{2}{|c|}{$\begin{array}{c}\text { 「地域冷暖房の場合」と「個別熱源方式の場合」の泠暖房料金比較 } \\
\text { 図 } 11 \text { モデル事務所の比較流れ }\end{array}$} \\
\hline \multicolumn{2}{|c|}{ 表 11 モデル事務所建物概要 } \\
\hline 建物概要 & 空調運転状態 \\
\hline 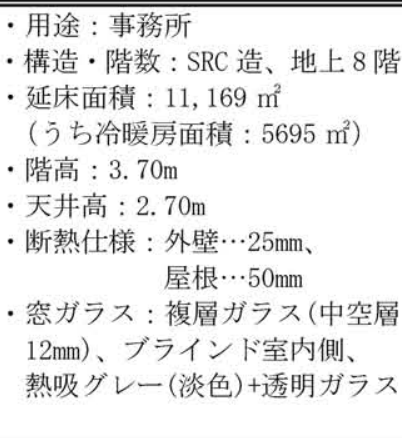 & 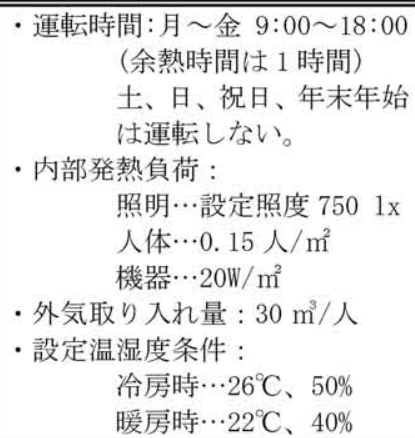 \\
\hline
\end{tabular}

（2006 年度）を、ソウル市は韓国地域暖房公社の熱料金単価（2006 年度）を適用する（表 13）。

表 15 に 3 都市におけるモデル事務所の 1 年間の月別地域冷暖房熱 料金の計算結果を示す。ただし、北京市は地域冷暖房による冷熱供 給事例が極めて少なく、冷房用熱料金の規程もないため計算を行っ ていない。地域冷暖房熱料金が不動産の月賃貸料金 (表 14) に対す る比率の対比で比較すると、暖房のみの場合は北京市が一番高く、 次が東京都でソウル市がもつとも低い。冷房も含めた 3 都市の比較 はできないが東京都はソウル市より大幅に高い結果となった。ソウ ル市の泠暖房熱負荷が東京都より大きいにもかかわらず、地域冷暖 房熱料金が安いということは、ソウル市の地域冷暖房の熱料金単価 が安いことがいえる。

4）「地域冷暖房の場合」と「個別熱源方式の場合」の比較 
表 12 北京市、ソウル市標準年気象データ構築方法注 4)

\begin{tabular}{|c|c|}
\hline EPW データ利用項目 & has データ項目への変換 \\
\hline $\begin{array}{l}\text { (1)Dry Buld Temperature } \\
\text { (units }{ }^{\circ} \mathrm{C} \text { ) }\end{array}$ & $\begin{array}{l}\text { 気温: }(1)+50.0) * 10 \\
\left.\text { (単位 } 0.1^{\circ} \mathrm{C}\right)\end{array}$ \\
\hline $\begin{array}{l}\text { (2) Relative Humidity } \\
\text { (units \%) }\end{array}$ & 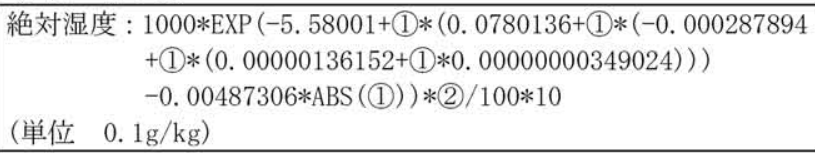 \\
\hline $\begin{array}{l}\text { (3) field Diredt Normal Radiation } \\
\text { (units } \mathrm{Wh} / \mathrm{m} 2 \text { ) }\end{array}$ & $\begin{array}{l}\text { 法線面直達日射量 : (3)*0.86 } \\
\text { (単位 } \mathrm{kcal} /(\mathrm{m} 2 \mathrm{~h}) \text { ) }\end{array}$ \\
\hline $\begin{array}{l}\text { (4) field Diffuse Horizontal Radiation } \\
\text { (units Wh/m2) }\end{array}$ & $\begin{array}{l}\text { 水平面天空日射量 : (4)*0.86 } \\
\text { (単位 } \mathrm{kcal} /(\mathrm{m} 2 \mathrm{~h}) \text { ) }\end{array}$ \\
\hline (5) field Opaque Sky Cover & 雲量 : 直接利用 \\
\hline $\begin{array}{l}\text { (6) field Wind Direction } \\
\text { (units degrees) }\end{array}$ & 風向 : 16 方位に変換 \\
\hline $\begin{array}{l}\text { (7) field Wind Speed } \\
\text { (units } \mathrm{m} / \mathrm{s} \text { ) }\end{array}$ & $\begin{array}{l}\text { 風速 : (7)*10 } \\
\text { (単位 } 0.1 \mathrm{~m} / \mathrm{s} \text { ) }\end{array}$ \\
\hline
\end{tabular}

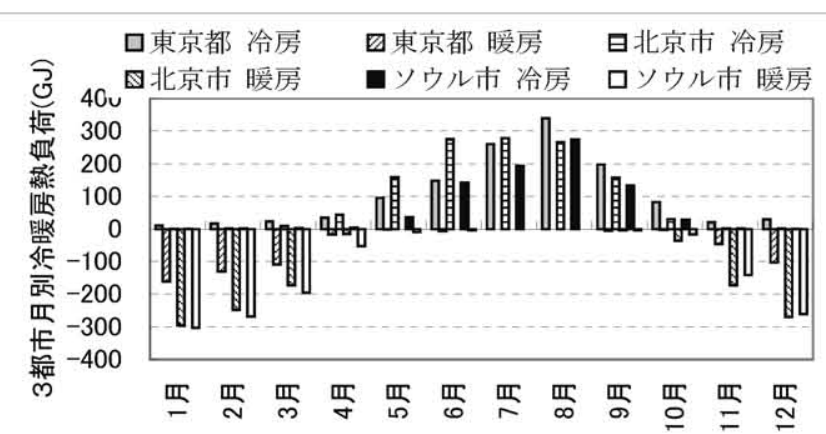

図 12 月別積算空調用熱負荷

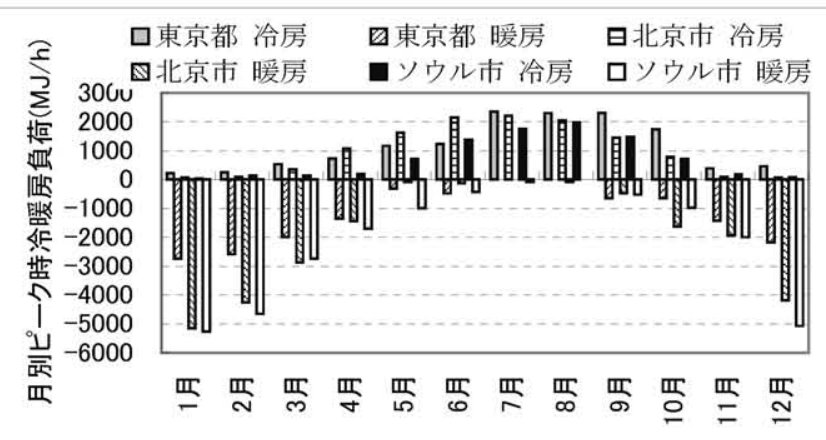

図 13 月別ピーク時空調用熱負荷

モデル事務所の冷暖房方式が個別熱源方式の場合を想定して冷暖房 料金を計算し、地域暖房熱料金と比較を行なう。個別熱源方式の場合、 空調設備の運転には様々な費用がかかるが、本研究では主な年間熱 源設備費、年間然料費、年間人件費、年間修理費を考慮する。表 16 に個別熱源方式の条件設定と諸費用の計算結果を示す。

年間熱源設備費は、2005-2007 年に竣工した東京都の事務所用建物 を調べた結果 ${ }^{33}$ 、熱源設備工事費が建物全体空調設備工事費の $18 \%$ であることから、北京市とソウル市も同様に全体空調設備工事費の $18 \%$ を熱源設備工事費とする。また、熱源設備の耐用年数を 15 年 に想定し、年間熱源設備費用 (金利と物価上昇を考慮しない) を計 算する ${ }^{3435)}$ 。年間燃料費は、個別熱源方式の熱源システムの COP を $0.6^{36)}$ と想定して各都市の泠暖房熱負荷より一次エネルギー使用量を 計算し、燃料使用量を求める。エネルギー使用現況より東京都とソ
表 13 事務所用地域冷暖房料金単価

\begin{tabular}{|c|c|c|}
\hline 都市名 & 基本料金 & 従量料金 \\
\hline 東京都 & $\begin{array}{l}320.868 \text { 円 } / \mathrm{MJ} / \mathrm{h} \text { (暖房) } \\
432.585 \text { 円 } / \mathrm{MJ} / \mathrm{h} \text { (冷房) }\end{array}$ & $\begin{array}{l}2.857 \text { 円/MJ (暖房) } \\
\text { 2.957 円/MJ (冷房) }\end{array}$ \\
\hline 北京市 & 30 元/熱供給面積 · 年 (定 & 額制） \\
\hline $\begin{array}{l}\text { ソウル } \\
\text { 市 }\end{array}$ & $\begin{array}{l}\text { 371. } 18 \text { ウォン/Mcal/h(暖房) } \\
3822 \text { ウホン/Mcal/h (冷房) }\end{array}$ & $\begin{array}{l}74.51 \text { ウォン/Mcal (暖房) } \\
94.57 \text { ウォン/Mcal (7, 8 月冷房) } \\
56.74 \text { ウォン/Mcal (7,8 月以外冷房) }\end{array}$ \\
\hline
\end{tabular}

表 14 モデル事務所 $\left(11,169 \mathrm{~m}^{2}\right)$ の不動産賃貸価格 ${ }^{30) 3132)}$

\begin{tabular}{|c|c|c|c|}
\hline 項目 & 東京都 & 北京市 & ソウル市 \\
\hline 貨貸単価 & 25800 円/坪 ・ 月 & 165 元 $/ \mathrm{m}^{2} \cdot$ 月 & 1934000 ウォン/坪・年 \\
\hline 月貨貸料 & $69,734,771$ 円 & $1,474,308$ 元 & 435, 617, 077 ウボ \\
\hline 円換算 & 同上 & $22,681,700$ & $43,561,708$ \\
\hline
\end{tabular}

表 15 モデル事務所における地域冷暖房熱料金

\begin{tabular}{|c|c|c|c|c|c|c|}
\hline \multirow{2}{*}{ month } & \multicolumn{2}{|c|}{ 東京都（円） } & \multicolumn{2}{|c|}{ 北京市（元） } & \multicolumn{2}{|c|}{ ソウル市（ウホン） } \\
\hline & 冷房 & 暖房 & 冷房 & 暖房 & 冷房 & 暖房 \\
\hline 1月 & 130,988 & $1,338,309$ & - & 41,500 & 31,996 & $5,834,589$ \\
\hline 2 月 & 155,659 & $1,201,552$ & - & 34,885 & 135,875 & $5,173,919$ \\
\hline 3 月 & 300,101 & 945,744 & - & 24,263 & 180,329 & $3,711,088$ \\
\hline 4月 & 416,261 & 481,869 & - & 2,072 & 232,255 & $1,073,022$ \\
\hline 5月 & 789,843 & 105,330 & - & 15 & $1,129,527$ & 254,742 \\
\hline 6 月 & 969,041 & 170,740 & - & 52 & $3,184,240$ & 115,811 \\
\hline 7月 & $1,785,939$ & 78 & - & 0 & $5,954,287$ & 13,858 \\
\hline 8月 & $1,993,493$ & 0 & - & 93 & $7,961,086$ & 0 \\
\hline 9 月 & $1,580,360$ & 217,728 & - & 579 & $3,149,762$ & 123,917 \\
\hline 10月 & 997,720 & 212,793 & - & 4,987 & $1,043,661$ & 389,943 \\
\hline 11月 & 229,510 & 585,876 & - & 24,337 & 188,681 & $2,672,596$ \\
\hline 12 月 & 289,854 & 993,009 & - & 38,095 & 91,835 & $5,065,696$ \\
\hline 合計 & $\begin{array}{r}9,638,769 \\
(13.8 \%)\end{array}$ & $\begin{array}{r}6,253,028 \\
(9.0 \%) \\
\end{array}$ & - & $\begin{array}{l}170,880 \\
(11.6 \%)\end{array}$ & $\begin{array}{r}23,283,533 \\
(5.3 \%) \\
\end{array}$ & $\begin{array}{r}24,429,182 \\
(5.6 \%) \\
\end{array}$ \\
\hline
\end{tabular}

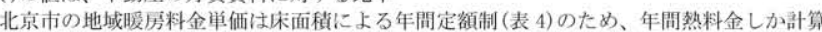

できないが月別空調用熱負荷(図 12)を参考として月別熱料金を記入

ウル市は都市ガスを北京市は石炭を燃料として選び、2009 年時点の 燃料単価より年間燃料費を計算する $\left.{ }^{37} 38\right)$ 39)。年間人件費は、常駐管 理人 1 人注5) を想定し、都市別の労働者の年間平均賃金をもとに年間 人件費を計算する。年間修理費は、年間人件費の半分 ${ }^{40)}$ とする。 
図 14 にモデル事務所の地域冷暖房料金と個別熱源方式料金を不動 産の月賃貸料金に対する比率の対比で比較した結果を示す。東京都 は地域泠暖房料金が個別熱源方式料金より高い結果となり、北京市 も暖房のみの比較であるが地域暖房料金が個別熱源方式料金より高 い結果となった。ソウル市は、地域泠暖房料金が個別熱源方式料金 より安い結果となっているが、それ以上に個別熱源方式料金がほか の都市より高いことに特徴がみられる。

モデル住宅とモデル事務所を利用した地域泠暖房の熱料金シミュレ ーション結果を総括すると、地域冷暖房の熱料金がルームエアコン 料金と個別熱源方式の料金より比較的に安いことと、特にソウル市 が安いことがわかる。その要因としては、各都市地域冷暖房の熱料 金設定の考え方の違いと熱源システムの原・燃料消費構成の違いな どが考えられる。

\section{7. おわりに}

北東アジア地域にある東京都、北京市、ソウル市の地域冷暖房を対 象に地域冷暖房事業の開始背景と最近 10 年間の変動、事業の現状、 熱料金体系等項目について調査を行い、比較を行なった。

(1) 3 都市の地域冷暖房の開始時期は異なり、それぞれ異なった社会 的背景のもとに導入されている。東京都は都市公害問題対策、北京 市は市民の住環境改善対策 ( 政府福祉事業)、ソウル市は大型ニュー タウン開発事業に採用されている。

(2) 3 都市の最近 10 年間の年間熱販売量をみると差はあるものの、 確実に増加している。なお、1998〜2007 年の増加率は北京市が最 大 $63 \%$ 、ソウル市が最大 $55 \%$ に対して、東京都はその半分の最大 $27 \%$ とどまる。

(3) 3 都市の 2006 年度の地域冷暖房の熱販売量は東京都とソウル市 の年間熱販売量が 1298 万 GJ と 1903 万 GJ に対して、北京市は桁違 いの 15808 万 GJ である。また、住宅向け熱販売量が地域冷暖房全体 で占める割合は東京都が $3 \%$ 、北京市が $66 \%$, ソウル市が $92 \%$ となっ ていて、東京都は業務用に極端に偏っている。

(4) 3 都市の地域冷暖房熱料金単価には多様性があり、東京都は熱 供給区域による差が大きい。北京市は熱供給区域に関倸なく市政府 が一律に熱料金単価を決める。ソウル市は事業者による違いはある が、その差額は小さい。

(5) 3 都市に同一のモデル建物 (住宅、事務所) を使用して地域冷 暖房熱料金シミュレーションを行った結果、北京市の熱料金が一番 高く、次に東京都で、ソウル市が最も安い。また、個別熱源方式と 比較するとソウル市は電気料金と L N G 料金が高く、地域冷暖房料 金が安くなった。

以上の比較結果を総括すると、東京都は地域冷暖房の熱料金が個 別熱源方式に比べてやや高く、政策上のインセンティブも不十分な ため 3 都市の中では普及度が遅い。北京市は、熱料金は高いが当初 に熱料金を無料化しその後も政府の地域暖房推進策を進めたため早 い段階から普及がかなり進んだ。ソウル市は政策上のインセンティ ブは無いものの、個別熱源方式の燃料となる電気と L NGの相対的 価格が他の 2 都市より格別に高いため、個別方式よりも地域冷暖房 料金が安く短期間に普及が進んだ、というような状況が見えてくる。 今回の検討は、3 都市の地域冷暖房事業を概観し、その中から、各 都市の地域泠暖房事業の現況と将来のあり方を考察することが目的
表 16 モデル事務所個別冷暖房の条件設定

\begin{tabular}{|c|c|c|c|}
\hline 項目 & 東京都 & 北京市 (暖房) & ソウル市 \\
\hline 全体設備工事費 & 32 千円 $/ \mathrm{m}^{2}$ & 600 元 $/ \mathrm{m}^{2}$ & 264 千ウオン $/ \mathrm{m}^{2}$ \\
\hline 熱源設備工事費 & 64333 千円 & 601 千元 & 530855 千ウホン \\
\hline 耐用年数 & 15 年 & 15 年 & 15 年 \\
\hline 燃料単価 & $\begin{array}{l}\text { 基本料金 (LNG): } \\
46200 \text { 円/件・只 } \\
\text { 単位料金 (LNG): } \\
52.45 \mathrm{円} / \mathrm{m} 3 \\
\end{array}$ & $\begin{array}{c}(\text { 石炭) } \\
0.75 \text { 元 } / \mathrm{kg}\end{array}$ & $\begin{array}{l}\text { 暖房用 (LNG) : } \\
719.63 \text { ウホン/m3 } \\
\text { 冷房用 (LNG) : } \\
396.39 \text { ウホン } \\
\end{array}$ \\
\hline 年間熱源設備費 & 4289 千円 & 40 千元 & 35390 千ウヴ \\
\hline 年間燃料費 & 4127 千円 & 105 千元 & 46981 千ウヴ \\
\hline 年間人件費 & 4459 千円 & 20 千元 & 31782 千ウが \\
\hline 年間修理費 & 2230 千円 & 10 千元 & 15891 千ウオン \\
\hline
\end{tabular}

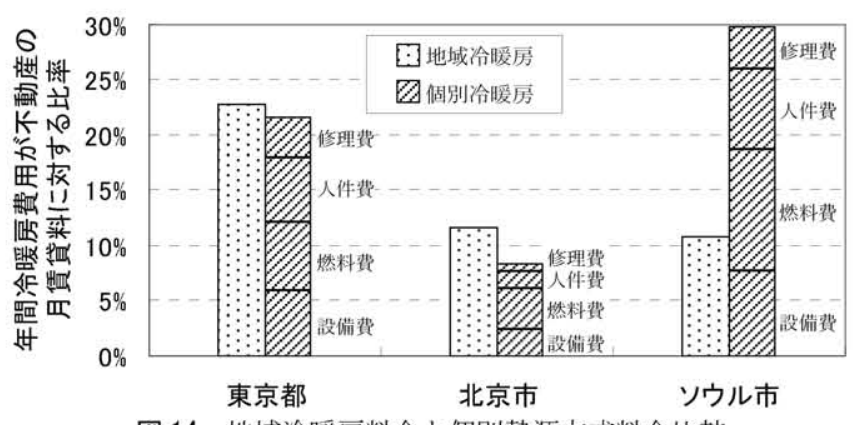

図 14 地域冷暖房料金と個別熱源方式料金比較

であったが、今後さらに料金設定の詳細、政策上のインセンティブ の詳細などを調查することにより 3 都市の地域冷暖房事業のこれか らのあり方及び将来像がよりはっきり見えてくると思われる。

\section{注}

注 1）東京都の地域冷暖房熱供給延床面積が建築延床面積全体に対する比率

注 2）北京市の地域暖房熱供給が建築延床面積全体に対する比率

注 3）ソウル市の地域暖房の統計は床面積ではなく、戸数を単位にするのが 一般的である。国土海洋部の不動産統計を参考にした。

注 4) has データ構築にあたり東京理科大学工学部 准教授 博士 (工学) 長井達夫氏に貴重なご指導を頂ました。

注 5）松浦技術士事務所 松浦房次郎氏に貴重なご指導を頂ました。

\section{参考文献}

1) 橘雅哉：西ドイツにおける地域椧暖房の現況，日本地域泠暖房協会，地域 冷暖房, 28 号, pp. 1-6, 1989. 10

2) Euro Heat \& Power, District Heat in Europe 2005 survey

3）河原透, 佐土原聡, 尾島俊雄 : 低温熱媒地域冷暖房導入に伴う東京の地区分 類に関寸る研究, 日本建築学会計画系論文報告集, No. 448, pp. 29-38, 1993.6

4）韋新東, 高偉俊, 李海峰, 尾島俊雄: 東京駅地区における既存熱供 給事業のネットワーク化に関する研究, 日本建築学会計画系論文集, No. 558 , pp. $57-62,2002.8$

5) 曾享麟：計量収費後供熱系統的調節和控制研究報告, 北京市供熱協会, 供 熱技術, 2009

6) 정 광 섭, 김 성 민 : A Study on the Effect of Variable Outdoor Temperature upon Heating Load Pattern in Apartment Housings with District Heating System, 大韓建築学会論文集, 計画系, 244 号,pp. 233240, 2009. 2

7) 황광일 :A Feasibility Study on the Selection of Apartment Districts in Seoul for Using the Low-temperature Renewable Energy System, 大韓 建築学会論文集, 計画系, 181 号,pp. 263-270, 2003.11

8) 東京都総務局統計部, 東京都の統計, 2006 
9) 北京市統計局, 北京統計年鑑, 2007

10）中国国家統計局，中国統計年鑑, 2007

11）ソウル市特別支庁，ソウル統計年報, 2007

12）横山厳 : 東京都と地域泠暖房, 日本地域冷暖房協会, 地域泠暖房, 1 号, pp. $14-17,1973.8$

13）大貫雅己：新宿副都心近況，日本地域冷暖房協会，地域冷暖房，2 号, pp. $15-16,1973.12$

14) baojiu：北京市供熱協会, 供熱論壇, 2007.10.25

15）趙明済 : 韓国における熱併給発電プラントと地域冷暖房事業の現況，日本 地域泠暖房協会，地域泠暖房，30 号,pp. 6-8, 1991.5

16）韓国地域暖房協会, 集団エネルギー, 3 号, p. 26,2006

17）日本熱供給事業協会, 熱供給事業便覧, 平成 11 年板 平成 20 年版, 19992008

18）中国国家統計局，中国統計年鑑，1999 2008

19) http://www. bdhg. com. cn (2009.6.20 参照)

20）北京市供熱協会，北京供熱，第 2 期, 2007.3

21) http://www. kienergy. net (2009.6.20 参照)

22）北京市供熱協会，北京供熱，第 3 期, 2007.7

23）北京市物価局, 京価（商）字, 372 号文献, 2001

24) 北京市発展・改革委員会, 京発改, 1886 号文献, 2008

25）エネルギー管理公団 (韓国), 省エネルギー統計, 地域暖房熱料金表, 2007

26）住環境計画研究所, 家庭用エネルギーハンドブック ,2009

27）于靚：中国における都市部集合住宅のエネルギー消費に関する研究，日本 建築学会環境系論文集 , No. 624,pp. 183-190, 2008.2
28）韓国エネルギー経済研究院, 家庭部門暖房設備別エネルギー消費統, 1995-2007

29) http://apps1. eere. energy. gov/buildings/energyplus/cfm/weatherdata. $\operatorname{cfm}(2009.12 .6$ 参照)

30) http://www. office-now. co. jp (2010.3.10 参照)

31） http://www. bei jingoffice. com. cn (2010.3.10 参照)

32) ソウル特別市, seoul survey, オフィス賃貸料統計, 2006

33）竣工設備調查用紙一覧, 空気調和衛生工学, 第 79 巻 2 号, 2005.2, 第 80 巻 2 号, 2006. 2, 第 81 巻 2 号, 2007.2

34）北京市建設工事費管理処，北京建設工事費事例（オフィス），京 ICP 備 05005276 号, 2008

35) 송승영, 김용인, 송규동 : Analysis of Factors Influencing upon the Cost and Cost Prediction based on the Actual Cost Data for Building Mechanical System, 大韓建築学会論文集, 計画系, 232 号, pp. 295-303, 2008. 2

36）渡部健一郎：実測調查による熱源システムのエネルギー利用効率に関する 研究, 日本建築学会環境系論文集, No. 599, pp. 103-110,2006.1

37）東京ガス，ガス料金のご案内，業務用・工業用選択約款 $-2,2009.9 .25$

38）北京市政管理委員会，熱供給価格推定,2008

39）韓国ガス公社, 用途別天然ガス価格, 2009.3.1

40）尾島俊雄著, 空気調和設備の経常費, 空気調和・衛生工学会編

2010年 6 月 10 日原稿受理， 2010 年12月 8 日採用決定） 